- The FOM estimation obtained with the Danish equation, little fitted for heavy carcasses, was 2.9 p. 100 too high for the French carcasses. The estimation made with the German equation, more adapted to French carcasses, resulted in a grading corresponding to the EEC standard in 72.5 p. 100 of the carcasses.

- Full programmings on dissection data were established for 3 sites of measurement in connection with carcass weight. They were different according as the tests were made on warm or cold carcasses. The muscle content was estimated $\left(\mathrm{R}^{2}=0.66\right)$ with a residual error RSD $=1.76$ p. 100 lean meat.

Reduced programmings on only 2 very representative sites, involving a loss of information, but a saving of time on the slaughterline, were suggested. Side fat thickness $X_{2}$, $8 \mathrm{~cm}$ from the midline, between the 3rd and the 4th vertebra was associated with the combined measurement $\left(X_{1}-X_{5}^{\prime}\right)$ of side fat and lean meat thickness, $6 \mathrm{~cm}$ from the midline, between the $3 \mathrm{rd}$ and the 4 th last rib. The muscle content was estimated with a residual error $\operatorname{RSD}=1.89$ p. 100 of lean meat, as follows :

$$
\mathrm{Y} E E C=35.47-0.30 X_{2}+29.82 \frac{X_{5}^{\prime}}{X_{5}^{\prime}+X_{4}} ;\left(R^{2}=0.61\right)
$$

- Within the weight class considered $(70-95 \mathrm{~kg})$, the Danish system was used to estimate the weight or the fat content as well a fleshiness combined with a subjective judgment of "types» : because of the variable distribution of lean weights, carcass net weight and length had to be taken into account. The contribution of $X_{2}$ and $X_{5}^{\prime} / X_{5}^{\prime}+X_{4}$ to the estimation of lean content and to that of fleshiness, was different.

- Utilization of the apparatusses on the slaughter line and the possibilities of objective measurement systems, are discussed. The constructors are requested to supply service guarantees for the maintenance of the probes and the electronic devices.

\title{
Prediction of the technological yield of Paris ham processing by using measurements at the slaughter-house
}

\section{B. JACQUET *, P. SELLIER **, J.P. RUNAVOT ***, D. BRAULT ****,} Y. HOUIX *****, C. PERROCHEAU ******, J. GOGUE**, J. BOULARD $* * *$

*C.T.S.C.C.V., Laboratoire de Charcuterie expérimentale, 78350 Jouy-en-Josas

** I.N.R.A., Station de Génétique quantitative et appliquée, 78350 Jouy-en-Josas

***I.T.P., Région Ouest, B.P. 3, 35650 Le Rheu

****I.N.R.A., Station de Sélection porcine, 35650 Le Rheu

***** I.T.P., Station de Sélection porcine, Le Transloy, 62450 Bapaume

*******E.D.E. du Morbihan, Station de Sélection porcine, 56430 Mauron

\section{France}

The aim of the trial was to determine by multiple linear regression analyses (1) to what extent measurements taken at the slaughter-house allow to predict the technological yield of Paris ham processing (weight of cooked ham/weight of defatted deboned fresh ham), and (2) which variables contribute most to the prediction. On a total of 215 female pigs from various breeds and crosses, the technological yield (TY) was measured and 35 predictor variables recorded at the slaughter-house either on the day of slaughter (D0) or on the day after (D1). All correlations were estimated on a within-slaughter day basis. The 11 D0 variables, which consisted of $\mathrm{pH} 1$, fibre optic value (FOP) and "Testron" value (TEST) on muscles easy of access on the intact half-carcass, were rather poor predictors of TY : the multiple correlation (R) between TY and the "best »2-variable prediction equation was only $R=0.50$. The $24 \mathrm{D} 1$ predictor variables consisted of subjective scores given to the ham, pH24, reflectance (REF), «time to get wet 》 (TGW, assessing 
water binding capacity), FOP and TEST values on different muscles. For the "best 2-variable equations, which combine the $\mathrm{pH} 24$ of Adductor femoris (AF) or Biceps femoris (BF) and the subjective score for wetness, R was around 0.72. For the «best»3-variable equations, where the same variables as above were combined with one FOP measurement, $\mathrm{R}$ was around 0.76 . When using only $\mathrm{pH} 24$ or FOP measurements which can be taken without cutting the carcass $R$ was around 0.68 and 0.72 with the best 2 and 3 variable prediction equations, respectively. A new "meat quality index» (MQI) was established on the basis of these results for use in progeny-testing stations : MQI was a 3-variable linear combination of $\mathrm{pH} 24$ of AF muscle, REF and TGW of $\mathrm{BF}$ muscle, and the correlation between MQI and TY was 0.718 .

\title{
The "Hampshire effect" on the technological qualities of pork
}

\author{
G. MONIN*, J. GRUAND**, Dominique LABORDE***, P. SELLIER **** \\ *I.N.R.A., Station de Recherches sur la Viande, Theix, 63122 Ceyrat \\ **I.N.R.A., Station expérimentale de Sélection porcine, 86480 Rouille \\ *** C.E.M.A.G.R.E.F., Division Technologie de la Viande, 63200 Riom \\ **:**: I.N.R.A., Station de Génétique quantitative et appliquée, 78350 Jouy-en-Josas
}

\section{France}

The aim of the experiment was to determine the technological properties of meat from Hampshire $(\mathrm{H})$ pigs, as compared to good quality meat from Large White (LW) pigs and to exudative meat from halothane-positive (HP) Pietrain pigs. All $\mathrm{H}$ and LW pigs were halothane-negative (HN). In 129 females and castrated males (45 LW, $20 \mathrm{HN}$ Pietrain, 27 HP Pietrain, $35 \mathrm{H}$ ) several quality characteristics were measured on raw meat and one ham was processed into cooked "Paris ham». Though $\mathrm{pH}$ was normal one hour post mortem in $\mathbf{H}$ pigs, which did not differ from LW pigs in this respects, pork from $\mathbf{H}$ pigs, especially females, showed a very low ultimate $\mathrm{pH}$ and the highest cooking loss in processing. However, meat was much less exudative when fresh and generally darker (reflectance measured at $630 \mathrm{~nm}$ ) in $\mathrm{H}$ than in $\mathrm{HP}$ Pietrain pigs. A very low ultimate $\mathrm{pH}$ occurred in muscle from $\mathrm{H}$ pigs owing to a very high «glycolytic potential » (essentially glycogen content). It is proposed to use the term "Hampshire type » to denote meat whose qualitative inadequacies basically result from an abnormally lowered ultimate $\mathrm{pH}$ and to keep the term «PSE » to refer to meat whose exudative state comes from a too rapid $\mathrm{pH}$ fall in the first few instants following slaughtering.

\section{Meat quality in four pig breeds : relationships with halothane sensitivity and plasma creatine phosphokinase activity}

\author{
P. SELLIER *, G. MONIN **, Y. HOUIX***, P. DANDO ****
}

*I.N.R.A., Station de Génétique quantitative et appliquée, 78350 Jouy-en-Josas

** I.N.R.A., Station de Recherches sur la Viande, Theix, 63122 Ceyrat

*** I.T.P., Station de Sélection porcine, Le Transloy, 62450 Bapaume **** I.N.R.A., Domaine de Galle, 18520 Avord

\section{France}

The halothane test was applied, at $25-30 \mathrm{~kg}$ live weight, to 1156 female pigs from four breeds : 365 Large White (LW), 244 French Landrace (FL), 397 Belgian Landrace (BL), 